\section{Ni av ti trafikkdødsfall skjer i lav- og mellom- inntektsland}

Rundt 1,27 millioner mennesker dør i trafikkulykker hvert år. Mer enn $90 \%$ av disse dødsfallene skjer i lav- og mellominntektsland, til tross for at disse landene kun har $48 \%$ av kjøretøyene i verden. Halvparten av de døde er myke trafikanter som fotgjengere, syklister og motorsyklister. Det er konklusjonene i den første globale evalueringen av veisikkerhet, publisert av Verdens helseorganisasjon (1). Rapporten inkluderer data fra 178 land, med totalt over $98 \%$ av verdens befolkning.

I noen utviklingsland er opptil $80 \%$ av dem som dør i trafikkulykker myke trafikanter. «Disse ulykkene roper på mer oppmerksomhet. Det trengs bygging av fortauer, planfrie fotgjengeroverganger og sykkelveier. Man må sette inn tiltak for å få mindre promillekjøring, lavere fart og økt bruk av hjelm. Dessuten er bedre traumebehandling nødvendig. Dette kan redde hundretusener av liv hvert år,» sier Etienne Krug, direktør i Department of Violence and Injury Prevention and Disability, WHO (2).

Mens trafikkdødeligheten i mange høyinntektsland har stabilisert seg eller er redusert de siste tiårene, er det en økning i andre deler av verden. Hvis denne trenden fortsetter, vil antall årlige dødsfall øke til rundt 2,4 millioner innen 2030 (2). Dødsraten er høyest i østlige middelhavsland og i Afrika, de laveste ratene finner man i Nederland, Sverige og Storbritannia.

Rapporten viser at mange land har mangelfull lovgivning. Under en tredel av landene innfrir kriteriet om lavere fartsnivå i boligstrøk, og kun i $57 \%$ av landene er det påbudt med setebelte for alle i bilen. I utviklingsland er denne andelen kun $38 \%$

«Kun $15 \%$ av landene har omfattende lover som dekker alle risikofaktorene som vi målte. Og til og med når lovgivningen er tilfredsstillende, rapporterer de fleste land at håndhevelsen er lav. (...) Som så ofte med folkehelsen er forebygging ikke bare en mulighet. Det er klart det beste valget,» sier Margaret Chan, generaldirektør i Verdens helseorganisasjon (3).

\section{Oda Riska}

oriska@hotmail.com

Tidsskriftet

\section{Litteratur}

1. Verdens helseorganisasjon. Global status report on road safety - time for action. Genève: WHO, 2009. whqlibdoc. who.int/ publications/2009/9789241563840_eng.pdf (29.7.2009).

2. WHO. Pedestrians, cyclists among main road traffic crash victims. WHO 15.6.2009. www.who.int/mediacentre/news/releases/ 2009/road_safety_report_20090615/en/ index.html (29.7.2009).

3. WHO. Programmes and projects. DirecorGeneral. www.who.int/dg/speeches/2009/ road_safety_address_20090615/en/index.html (29.7.2009).

\title{
Verdas høgaste dødstal for mødre
}

\author{
Medisinstudentanes humanitæraksjon 2009 skal prøve å redusere dei \\ høge dødstala for born og mødre i Sierra Leone. MedHum-leiarane \\ i Oslo, Tromsø, Trondheim og Bergen drog nyleg til landet for å lære \\ meir om prosjektet.
}

Sierra Leone er eit land med rundt seks millionar innbyggjarar. Det gjekk gjennom ein forferdeleg borgarkrig i åra 1991-2002 og låg i ruinar. No har det skjedd positive endringar.

Sierra Leone har verdas høgaste dødstal for mødre - omkring 2000 per 100000 levandefødde born $(1,2)$. Livstidsrisikoen for mødredød er 1: 8 (2). Risikoen for at eit barn døyr før fylte fem år er 269 per 1000 levandefødde (3). Dei høge dødsratane har mange årsaker, spesielt er malaria, pneumoniar, underernæring og fødselskomplikasjonar viktige faktorar. Middellevealderen er blant verdas lågaste - gjennomsnittleg ca. 40 år (2). Blir ein sjuk i dette landet, er risikoen for å døy svært stor. Ein kan berre prøve å tenkje seg dette - i distrikta er sjukehusa på storleik med helsestasjonar, og det finst ingen blodbankar.

\section{Samarbeid med UNICEF}

Samarbeidspartnar for MedHum-aksjonen 2009 er UNICEF (4). Prosjektet heiter Sierra Leone Survival Kit. Pakka inneber førebygging av sjukdom gjennom vaksinar og kosttilskot, opplæring av helsepersonell og haldningsskapande arbeid og behandling av dei vanlegaste bornesjukdommane malaria, diaré, akutte luftvegsinfeksjonar og underernæring (3). Saman med represen-

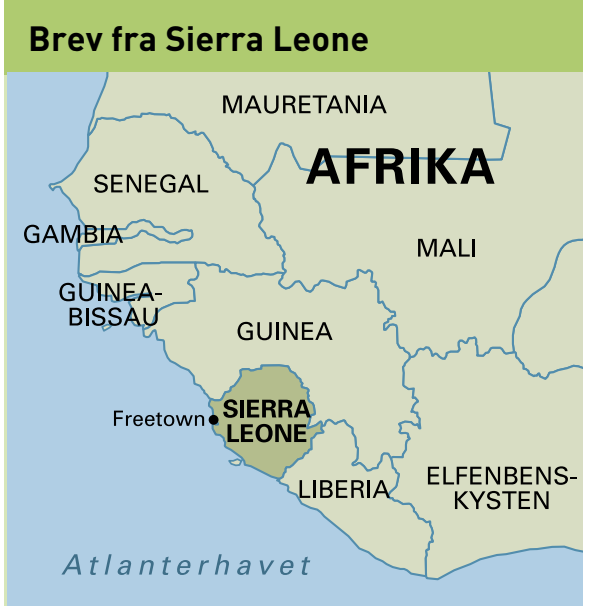

tantar for UNICEF drog me til landet i september 2008.

Me vart frakta i helikopter frå flyplassen i hovudstaden Freetown til sentrum. Dei neste dagane køyrde me Landrover på vegar som hadde fleire hol enn flate parti. Me reiste fyrst til den nest største byen, Bo. Her vitja me ein helsestasjon som nytta modellen «survival kit». I løpet av veka såg me både små helseklinikkar ute i distrikta og eit større sjukehus i Freetown. Det at UNICEF og organisasjonar som Leger Uten Grenser er til stades i landet er viktig.

Landet har enorme naturressursar, men har til no ikkje klart å nytte dei særleg godt. Det finst mat, men folk manglar pengar. Dei veit ikkje kor viktig det er med eit balansert kosthald og et nesten berre ris. Det kan gje feilernæring og underernæring, som gjer at mange ungar døyr (3).

Tenåringsgraviditetar er også eit stort problem. Jentene byrjar på skulen, men når dei blir 13 år, blir mange gifta bort. Så blir dei gravide, og då sluttar dei på skulen. Ofte er ekteskapet arrangert og mannen svært mykje eldre. I UNICEF håpar ein at dette kan endrast gjennom opplysing og utdanning. Ein ser likevel stor framgang, og alderen til mødrene aukar stadig!

\section{Morlai}

I løpet av veka blei eg kjent med Morlai, ein 22 år gamal gut. Han studerte kommunikasjon på universitetet i Freetown og hadde no eit «internship» hos UNICEF. I Sierra Leone er det vanleg at ein gjeng rundt til familiemedlemmar og bed om pengar til utdanning. Sidan Morlai kjem frå ein fattig familie, var dette vanskeleg. Etter ei stund hadde han klart å skaffe nok pengar, og onkelen hans sa ja til å la han bu hjå seg. Då krigen kom, måtte Morlai flykte til nabolandet Guinea. Der var han i eitt år. Då han kom tilbake, var onkelen død. Det gjorde at han vart tvungen til å ta eitt år fri for å arbeide. Gjennom arbeid på eit hotell blei han kjent med ei eldre dame frå Skottland. Ho kontakta han seinare og sa ho ville 


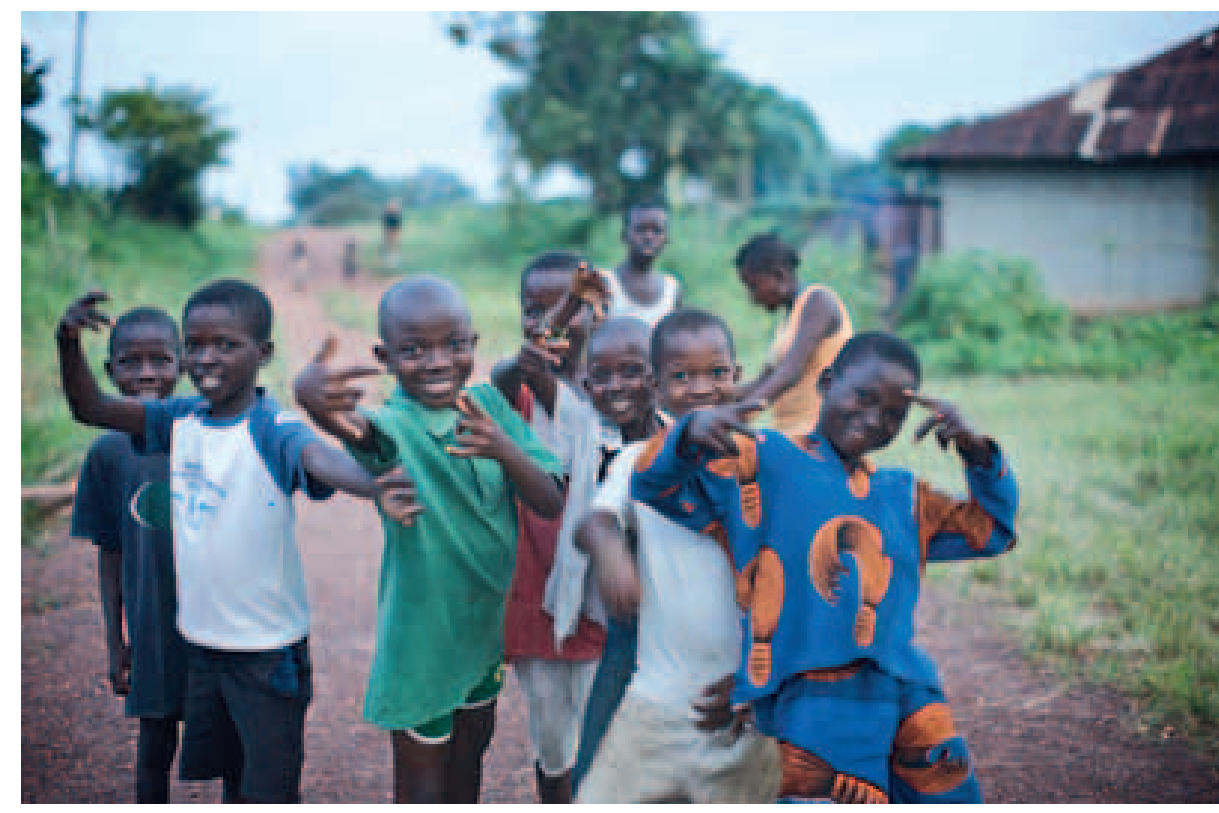

Glade gutar i eit fattig land. Foto Danny Twang

betale for det siste året hans på vidaregåande. Dette gjorde at han kunne byrje på universitetet. I Sierra Leone kostar eitt år på universitet rundt tusen dollar. Det å byrje på universitetet og få seg ei utdanning er for ungdommar som Morlai billetten ut av eit liv i ekstrem fattigdom.
Me møtte ei rekke ressurssterke og glade menneske. Det høyrest som ein klisjé, men det er sant. Korleis kan ein vere lukkeleg i ekstrem fattigdom? Eg fekk inntrykk av at folk ikkje hadde det så ille som statistikken viste, men då eg sat på flyet heim,

\section{Lukkeleg og fattig?}

slo alle inntrykka plutseleg inn. Eg innsåg at alle dei positive menneska eg hadde møtt, hadde gjort at eg ubevisst ikkje hadde tatt inn over meg den ekstreme fattigdommen dei lever under. Eg håpar at eg ein dag kan reise tilbake for å gjere ein innsats som lege og medmenneskje i eit fantastisk land.

\section{Det nyttar!}

Med hjelp frå Medisinstudentanes Humanitæraksjon vil UNICEF-pakka redde mange menneskeliv. Eg har vore der og sett at dette er eit prosjekt som nyttar! Gå inn på www.medhum.no for meir informasjon!

\section{Bjørg Bakke}

bba083@student.uib.no

Medisinstudentanes humanitæraksjon

Oppgitte interessekonflikter: Ingen

\section{Litteratur}

1. Wikipedia. Maternal death. http://en.wikipedia.org/ wiki/Maternal death (16.6.2009).

2. Unicef. At a glance: Sierra Leone: statistics. www.unicef.org/infobycountry/sierraleone_ statistics.html (16.6.2009).

3. WHO. Countries. Sierra Leone. www.who.int/ countries/sle/en/ (17.6.2009).

4. Våge RA. MedHum 2009 samarbeider med UNICEF. Tidsskr Nor Legeforen 2009; 129: 1028.

Manuskriptet ble mottatt 18.6. 2009 og godkjent 30.7. 2009. Medisinsk redaktør Erlend Hem. 